\title{
Religious Educators:
}

\section{A Psychological Study of Qur'anic Verses regarding al-Rahmah}

\section{Idi Warsah}

Institut Agama Islam Negeri (IAIN) Curup, Indonesia

idiwarsah@gmail.com

DOI: $10.29240 /$ alquds.v4i2.1762

Submitted: 2019-06-26 | Revised: 2020-08-23 | Accepted: 2020-09-05

\begin{abstract}
This study applied a library research to explore and understand in-depth information as regards the essence of al-rahmah in Qur'anic verses as well as to integrate the concepts of al-rabmah with educational psychology concepts using a normative qualitative approach by analyzing the meanings of al-rahmah repeated 338 times in the Qur'an. The present study made efforts to find new concepts, especially on ideal educators' personalities. Very contrary to the conclusion drawn by Amaechi stating that Islam provides both the ideological framework and the network platform upon which violent elements develop, the current study concluded that educators who have the characteristics of al-rahmah are those who have three religious personalities such as rabbany, nabany, and insany that are bound by a strong belief in the power of Allah, observe the Islamic law well, and are fully aware that Allah always oversees their activities. With the aforesaid personalities, good educators are also associated with having high spirituality and religiosity (fearing of Allah and having noble characters), having good competences, extensive knowledge as well as being intelligent, being future-oriented, communicative (conveying knowledge with patience, sincerity, and with understandable methods), open to critic, authoritative, fair, non-discriminatory, and pleasant, and having polite speech.
\end{abstract}

Keywords: Religious Educator; Psychological study; al-Rahmah

\section{Introduction}

Goodlad in Thomas Armstrong as cited in Warsah describes that in learning processes and when being in the classrooms, students generally only listen to lectures or teacher's explanations about one fifth of the school day. ${ }^{1}$ In such a way, most of the teaching processes take place without meaningful

${ }^{1}$ Idi Warsah, "Pendidikan Keimanan Sebagai Basis Kecerdasan Sosial Peserta Didik: Telaah Psikologi Islami," Psikis: Jurnal Psikologi Islami 4, no. 1 (2018): 1-16. 
interactions between the teacher and students. The aforesaid condition is considered no longer relevant in today's era of industrial revolution 4.0.

Hasbullah as cited in Warsah argues that the foregoing portrayal of learning system represents a theory known as teacup and teapot, in which the teacher becomes a pot continuously pouring water into the cup regardless of the cup's volume. ${ }^{2}$ It depicts that the teacher does not take account of students' potency and abilities. In so doing, the students only receive information provided by the teacher without developing their own existing potency, resulting in a passive learning process, non-mindful understanding, and boring learning engagement.

Educators must be aware that every person is born with different potencies. ${ }^{3}$ Every educator must be aware that if students' potency is not well developed, their intelligence, skills, and competences will not properly develop as well. Therefore, educators must be able to develop better learning processes, fostering care for each student and paying attention to their potential with loving care. ${ }^{4}$

Gardner and his colleagues at Harvard University proposed eight types of potential intelligence in humans that must be well developed. ${ }^{5}$ They are comprised of linguistic, logical, mathematical, spatial, kinesthetic, musical, interpersonal, intrapersonal, and naturalist intelligent types. This theory of intelligence is named multiple intelligences. Their thesis is the answer that every human being has all kinds of intelligence, but the intelligent development is different from person to person. According to Gardner, every educator must consider that recognizing and training the diversities of all types of students' intelligence and all combinations of those types are important to pave the way for learning which conforms to how the brain works. ${ }^{6}$ Hence, the educators can

\footnotetext{
${ }^{2}$ Warsah.

3 Jianhong Shen and Thomas J Palmeri, "Modelling Individual Difference in Visual Categorization," Visual Cognition 24, no. 3 (2016): 260-83, https://doi.org/10.1080/13506285.2016.1236053. See also Melodie Rosenfeld and Sherman Rosenfeld, "Developing Effective Teacher Beliefs about Learners: The Role of Sensitizing Teachers to Individual Learning Differences," Educational Psychology: An International Journal of Experimental Educational Psychology 28, no. 3 (2008): 245-72, https://doi.org/10.1080/01443410701528436. See also Mary Kalantzis and Bill Cope, "Learner Differences in Theory and Practice," Open Review of Educational Research 3, no. 1 (2016): 85-132, https://doi.org/10.1080/23265507.2016.1164616.

${ }^{4}$ Queenie A.Y. Lee and Mantak Yuen, "The Role of Teacher Care in Determining Academic Success of Community College Students: A Case Study from Hong Kong," Pastoral Care in Education 37, no. 2 (2019): 94-107, https:/ / doi.org/10.1080/02643944.2019.1618376.

${ }^{5}$ Howard Gardner, Multiple Intelligences: Kecerdasan Mayemuk: Teori Dan Praktis, Diterjemabkan Oleh Alexander Sindoro (Jakarta: Interaksara, 2013).

${ }^{6}$ Gardner.
} 
sustainably help students learn and establish learning models which meet the nature of students' differences. ${ }^{7}$

How educational processes pay attention to the potential of students' intelligence is important, and this effort unconsciously also contributes to the development of the students' divine potential towards total servitude to Allah. Teachers are required not only to be professional and capable of delivering teaching materials to their students, but also to have a good personality, care, and love for their profession and students, so there is a strong relationship between teachers and students. ${ }^{8}$

However, teachers are ordinary humans who have various personalities. There are still found many teachers who have not been able to position themselves as partners for their students, and they seem to consider students no more than just the objects in classroom learning processes. As to cope with the aforementioned cases, Kuusisto, Arniika, and Gearon on the description of education in Finland proposed a synthesis that the presences of professional religious educators are of paramount importance so that appropriate treatments for students, better curriculum changes, and convenient community transformation could be established. ${ }^{9}$

The current study seeks to explore and understand in depth information on the substance of the verses regarding al-rahmah in the Qur'an and integrate its concepts with educational psychology concepts using a normative qualitative

${ }^{7}$ Renáta Tichá et al., "Instructional Strategies for Inclusive Classrooms: PALS, Cooperative Learning, Direct Instruction and Play-Based Strategies," in Inclusive Education Strategies: A Textbook, ed. Paula Frederica Hunt Renáta Tichá, Brian H. Abery, Christopher Johnstone, Alvard Poghosyan (Armenia: UNICEFF country offi, 2018), 105-23. See also Brian H. Abery and Marianna Harutyunyan, "Enhancing the Social and Psychological Inclusion of Students with Special Education Needs," in Inclusive Education Strategies: A Textbook, ed. Paula Frederica Hunt Renáta Tichá, Brian H. Abery, Christopher Johnstone, Alvard Poghosyan (Armenia: UNICEFF country offi, 2018), 166. See also C. A. Tomlinson, "Grading and Differentiation Paradox or Good Practice? Theory into Practice” 44, no. 3 (2005): 262-69.

8 Jing Li, Xiaohong Yang, and Cheryl J. Craig, "A Narrative Inquiry into the Fostering of a Teacher-Principal's Best-Loved Self in an Online Teacher Community in China," Journal of

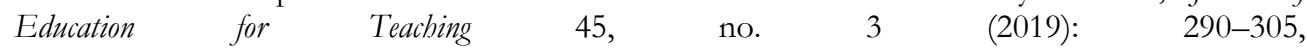
https://doi.org/10.1080/09589236.2019.1599508. See also Katriina Maaranen et al., "An Idealistic View of Teaching: Teacher Students' Personal Practical Theories," Journal of Education for Teacbing 42, no. 1 (2016): 80-92, https://doi.org/10.1080/02607476.2015.1135278. See also E. Jayne White and Mikhail Gradovski, "Untangling (Some) Philosophical Knots Concerning Love and Care in Early Childhood Education," International Journal of Early Years Education 26, no. 2 (2018): 201-11, https://doi.org/10.1080/09669760.2018.1458602.

${ }^{9}$ Kuusisto, Arniika, and Liam Gearon, "The Life Trajectory of the Finnish Religious Educator,” Religion \& Education 44, no. 1 (2017): 39-53. 
approach by analyzing the meanings of al-rahmah which is repeated 338 times in the Qur'an. ${ }^{10}$ Through interpretation analysis and psychological studies, this study can find new concepts on the types of educators' personalities in order to create an ideal education and provide scientific contributions to the development of Islamic educational psychology in the future.

The current study is a library research which seeks to explore and understand in depth information pertinent to the essence of al-rabmah in Qur'anic verses as well as to integrate the concepts of al-rabmah with educational psychology concepts using a normative qualitative approach by analyzing the meanings of al-rahmah which is repeated 338 times in the Qur'an. ${ }^{11}$ Through interpretative analysis and psychological studies, the present study can find new concepts on the types of educators' personalities in order to create an ideal education and provide scientific contributions to the development of Islamic educational psychology in the future. The interpretations rest upon Imam al Alusy's. His tafsir is chosen because it uses the tablili approach with comparative sources from ar-ra'yu and bil ma'stur.

\section{Findings and Discussion}

\section{Educator's Personality}

In learning processes, a teacher plays some important roles. The teacher's behavior and teaching methods provide strong influences and patterns for fostering students' behavior and personalities. Therefore, teacher's behavior has to be developed in such a way that it can give good influences to students. The teacher's roles are not only to transfer knowledge but also to help students to be engaged in the processes of knowledge construction. ${ }^{12}$ In this regard, students are regarded as not only the objects but also the subjects in education. The entire behavior of a teacher in carrying out his/her duties as an educator has implications for students' personalities. At schools, teachers act as designers

${ }^{10}$ Muhammad Fuad Abdul Baqy, Mu'jam Al-Mufharas Li Al-Fadzৃil Qur'anil Karim (AlQahirah: Darul Hadis, 1996).

${ }^{11}$ Baqy.

${ }^{12}$ James P Lantolf and Steven L Thorne, "Sociocultural Theory and Second Language Learning," Theories in Second Language Acquisition, 2006, 197-221, https://doi.org/10.1177/0022219409345018. See also Lev Vygotsky, "Interaction between Learning and Development," Readings on the Development of Children (New York, 1978), https://doi.org/10.1016/S0006-3495(96)79572-3. See also Mamour Choul Turuk, "The Relevance and Implications of Vygotsky's Sociocultural Theory in the Second Language Classroom," ARECLS 5 (2008): 244-62. 
or planners, instructors, and managers of students' learning as well as role models for their students. ${ }^{13}$

The teachers' roles at schools are determined by their positions as an adult and as a teacher. As a teacher, they must show proper behavior (as a role model for their students). Teachers who behave badly will damage their images as a teacher and in turn conceivably damage students' personalities. Therefore, if there are students who show deviant behavior, it might be due to the contribution of the teachers' behavior that cannot be a good example.

Another important factor for teachers is their personalities. ${ }^{14}$ In the current teaching professional duties, teachers not only must have a number of academic competencies such as the mastery of learning materials, skills at designing, managing, and evaluating learning, and abilities to utilize teaching aids and learning media, but also must show maturity and inspiring personalities. $^{15}$

'Teachers' behavior is generally a description of their personalities in terms of acting, speaking, getting along, dressing, making decisions, and showing attitudes when they are confronted with problems. For young students, teachers are present as important examples for their growth. A teacher is the first person, after the students' parents, influencing the development of the students' personalities. ${ }^{16}$ If the teacher's behavior or morals are not good, students will generally emulate the teacher. It is natural because elementary and middle school-age children are easily influenced by the people they admire. Anam's thesis emphasizes that educators are more than mere living things

${ }^{13}$ Michaela Pörn and Katri Hansell, "The Teacher's Role in Supporting Two-Way Language Learning in Classroom Tandem," International Journal of Bilingual Education and Bilingualism, 2017, 1-16, https://doi.org/10.1080/13670050.2017.1379946. See also Vlatka Domović, Vizek Vidović Vlasta, and Dejana Bouillet, "Student Teachers' Beliefs about the Teacher's Role in Inclusive Education," European Journal of Special Needs Education 32, no. 2 (2017): 175-90, https://doi.org/10.1080/08856257.2016.1194571. See also Anne Feryok, "Teaching for Learner Autonomy: The Teacher's Role and Sociocultural Theory," Innovation in Language Learning and Teaching 7, no. 3 (2013): 213-25, https://doi.org/10.1080/17501229.2013.836203.

${ }^{14}$ Lajos Göncz, "Teacher Personality: A Review of Psychological Research and Guidelines for a More Comprehensive Theory in Educational Psychology," Open Review of Educational Research 4, no. 1 (2017): 75-95, https://doi.org/10.1080/23265507.2017.1339572.

${ }^{15}$ Mangkunegara, AA Anwar Prabu, and Mela Puspitasari, "Kecerdasan Emosi Guru, Stres Kerja, Dan Kinerja Guru SMA," Jurnal Kependidikan: Penelitian Inovasi Pembelajaran 45, no. 2 (2015).

${ }^{16}$ Richard E. Lucas and M. Brent Donnellan, "Enhancing Transparency and Openness at the Journal of Research in Personality," Journal of Research in Personality 68 (2017): 1-4, https://doi.org/10.1016/j.jrp.2017.03.002. 
inside the classrooms since educators per se are intrinsically the people who guide children towards maturity. ${ }^{17}$

The teachers' attitude in dealing with all problems when interacting with students, colleagues, principal, and educational staffs will be seen, observed, assessed, and imitated by students. The favored attitude in treating students is the thing that is most quickly felt by students because all children expect attention and affection from their teachers. According to Ayusita as cited in Septianingrum, this attitude refers to social competences that teachers should possess.18 Therefore, for the sake of achieving the school goals, all teachers must have good personalities that can be emulated by the students. With perceiving teachers' good personalities, students will further be open and interested in the learning subjects delivered to them. In this way, learning processes will be meaningful and have positive implications for the development of students' potential and creativity.

Students' potential and creativity will develop if they are given opportunities to do their own learning activities that have been programmed. ${ }^{19}$ Besides, in order to promote the development of students' potential and creativity, good human resources and supportive elements must be available. Those elements range from curriculum, school facilities and infrastructure, management, to teachers who are qualified, religious, have good personalities, broad-minded, and also have adequate experiences to encourage their efforts to be good learning models and learning providers.

Learning processes with good, effective, and efficient methods will be contributive to support the attainment of learning targets, and establish good interactions between the teachers and students. This is in line with Hilgard and Bower as cited in Indrawati ${ }^{20}$ that learning has a relationship with changes in individual behavior towards a particular situation as an impact of repeated experiences in the situation. In brief, teachers take part in being learning facilitators and learning models for students.

${ }^{17}$ Saeful Anam, "Tinjauan Filosofis Tentang Pendidikan: Analisa Terhadap Pendidik Dalam Pendidikan Islam,” MIY AH: Jurnal Studi Islam 12, no. 1 (2017): 1-18.

18 Anisa Septianingrum, "Studi Kompetensi Sosial Dan Kepribadian Mahasiswa Program PPL (Praktik Pengalaman Lapangan) Prodi Pendidikan Sejarah Angkatan 2010 Di Kota Magelang," Risalab 3, no. 10 (2016).

${ }^{19}$ Mansoureh Hajhosseini et al., "Critical Thinking and Social Interaction in Active Learning: A Conceptual Analysis of Class Discussion from Iranian Students' Perspective," Curriculum \& Teaching Studies, 2016, 1-9, https://doi.org/10.1080/2331186X.2016.1175051; Maaranen et al., "An Idealistic View of Teaching: Teacher Students' Personal Practical Theories."

${ }^{20}$ Farah Indrawati, "Pengaruh Kemampuan Numerik Dan Cara Belajar Terhadap Prestasi Belajar Matematika," Formatif: Jurnal Imiah Pendidikan MIPA 3, no. 3 (2015). 


\section{The Nature of Personality}

Every individual, including the teacher, has different and unique personalities. According to psychologists, the term personality has more meanings than a mere attractive trait. ${ }^{21}$ Personality is the overall quality of one's behavior. ${ }^{22}$ Personality includes a relatively enduring pattern of thoughts, feelings, and behaviors that distinguish each other. ${ }^{23}$ Personality also refers to patterns of behavior, values, thoughts, motives, and emotions which characterize an individual. ${ }^{24}$ Individual personalities in general can fall into some categories such as conscientiousness, extraversion, neuroticism, agreeableness, and openness. ${ }^{25}$

${ }^{21}$ Toshinori Kitamura et al., "Intergenerational Transmission of Parenting Style and Personality: Direct Influence or Mediation?," Journal of Child and Family Studies 18, no. 5 (2009): 541-56, https://doi.org/10.1007/s10826-009-9256-z. See also Rose M.E. Huver et al., "Personality and Parenting Style in Parents of Adolescents," Journal of Adolescence 33, no. 3 (2010): 395-402, https://doi.org/10.1016/j.adolescence.2009.07.012.

22Jalaluddin, Psikologi Agama (Jakarta: Raja Grafindo Persada, 2016).

${ }^{23}$ Brent W. Roberts and Daniel Mroczek, "Personality Trait Change in Adulthood," Current Directions in Psychological Science 17, no. 1 (2008): 31-35.

${ }^{24}$ Rachma, Diah Ayu, and Seger Handoyo, Hubungan Antara Kepribadian Dengan Kemampuan Adaptasi Lintas Budaya Pada Expatriate Leader (Surabaya: Universitas Airlangga, 2016).

${ }^{25}$ Ridhi Arora and Santosh Rangnekar, "Moderating Mentoring Relationships and Career Resilience: Role of Conscientiousness Personality Disposition," Journal of Workplace Behavioral Health 31, no. 1 (2016): 19-36, https://doi.org/10.1080/15555240.2015.1074052. See also Murray R. Barrick, Michael K. Mount, and Judy P. Strauss, "Conscientiousness and Performance of Sales Representatives: Test of the Mediating Effects of Goal Setting," Journal of Applied Psychology 78, no. 5 (1993): 715-22. See also H. Schuler and M. Prochaska, "Development and Construct Validation of a Job-Related Achievement Motivation Test. Diagnostica , 46 , 61 - 72.," Diagnostica 46 (2000): 61-72. See also Nikos Bozionelos et al., "Mentoring Receipt and Personality: Evidence for Non-Linear Relationships," Journal of Business Research 67, no. 2 (2014): 171-81, https://doi.org/10.1016/j.jbusres.2012.10.007. See also L. F. Carvalho et al., "Obsessive-Compulsive Personality Disorder Screening Cut-off for the Conscientiousness Dimension of the Dimensional Clinical Personality Inventory 2," European Journal of Psychiatry 33, no. 3 (2019): 112-19, https://doi.org/10.1016/j.ejpsy.2019.05.002. See also Thomas Suslow et al., "Using Implicit Association Tests for the Assessment of Implicit Personality Self-Concepts of Extraversion and Neuroticism in Schizophrenia," Psycbiatry Research 218, no. 3 (2014): 272-76, https://doi.org/10.1016/j.psychres.2014.04.023. See also Brittany C Speed et al., "RUNNING TITLE: Parenting Style and Observational ERPs TITLE: Authoritarian Parenting Predicts Reduced Electrocortical Response to Observed Adolescent Offspring Rewards Amanda R. Levinson, B.S.," 2016. See also Brittany C. Speed et al., "Personality and Emotional Processing: A Relationship between Extraversion and the Late Positive Potential in Adolescence," Psychophysiology 52, no. 8 (2015): 1039-47, https://doi.org/10.1111/psyp.12436. See also Velichko H. Valchev et al., "Beyond Agreeableness: Social-Relational Personality Concepts from an Indigenous and Cross-Cultural Perspective," Journal of Research in Personality 48, no. 1 (2014): 17-32, 
If the concept of personality is associated with teachers, especially those of Islamic education, the above highlights cannot only be mere bases of consideration, specifically in terms of promoting students' development. Teachers in Islamic education are expected to capably show good traits such as being honest, open, loving, helpful, disseminating, cooperative, independent and so on. Those traits align with the messages regarding al-rahmah as described in Qur'anic verses. Teachers' good personalities are highly urgent for the development of students' behavior. Good teachers are not only competent and skilled at delivering learning materials but also capable of maintaining inspiring attitude, behavior, appearance, and speech.

\section{Personality in the Perspective of Islamic Psychology}

In Islamic studies, the most essential thing in humans is the immaterial or spiritual substance. Human mind includes cognitive mind, lust, heart, and soul. Humans consist of bodies and spirits, but the essence of both is the spirit, while the body is only a medium in reality. When the body separates from the spirit (death), then only the body dies, while the spirit will continue its existence into the barzah realm. In other words, the personality portrayed in the form of behavior is the result of collaboration in encouraging the immaterial potency (soul/spirit) and the material one (body).

Immaterial potency (soul) is a hidden potency in humans. The term of potency is described in the Qur'an with the following words: rub (spirit), al-'aql (reason), nafs (soul), al-qalb (heart), al-fuad (heart), and al-fitrah (basic human potential), which must be actualized in the real life in this world through the processes of education, henceforth it can be accounted for before Him in the Hereafter. Meanwhile, al-Ghazāli used four terms to refer to the human soul: Rub (spirit), 'Aql (reason), Nafs (soul), and Qalb (heart).

Humans' potency is given by God. With their potency, humans are made different from other creatures. As explained above, humans are created from dirt and the Divine Spirit through detailed but inexplicable process. If the whole structure of the soul is still within the scope of the 'frame of fitrah' as described above, the soul (nafs) will not lose its humanity. On the other hand, if the forces of the human soul go beyond that nature of fitrah, then humans will come out of their nature, both in positive and negative terms.

In a positive sense, humans are considered to have lost their insāniyah personality, so they then resemble 'angels'. Meanwhile, in the negative sense,

https://doi.org/10.1016/j.jrp.2013.10.003. See also Yoshihiko Matsumoto et al., "Implication of the DGKH Genotype in Openness to Experience, a Premorbid Personality Trait of Bipolar Disorder," Journal of Affective Disorders 238, no. May (2018): 539-41, https://doi.org/10.1016/j.jad.2018.06.031. 
humans are considered to have lost their spiritual power, so they fall into a circle of shaitan and can be said to have a satanic personality.

\section{Good Personalities of Educators}

The term good is actually relative, since it really depends on the person or the one who judges the said person. Teaching is a complex business, so it is difficult to determine how good teaching is, as well as to assess good teachers. The following descriptions explain some generally accepted principles with respect to good teachers' characteristics.

First, good teachers understand and respect students. Teaching is a process of humanity. Students are full human beings who are entitled to the treatment of respect from teachers, so someday they grow into adult humans who are respected and also have respect for others. Second, good teachers respect on the delivered materials. Teachers must sufficiently master the materials they teach. Mastering learning materials is not identical to memorizing. Third, good teachers adjust the teaching methods to the learning materials. The learning materials can be delivered with certain methods, i.e., lectures, questions and answers, discussions, assignments, and field works or excursions. The methods used by teachers must be relevant to the learning materials.

Fourth, good teachers adapt learning materials to individual abilities. Students as individuals have different abilities. In other words, students' abilities vary in many ways. Usually, teachers make efforts to adjust to the lessons with the average abilities in the class. Fifth, good teachers activate students in the context of learning. Learning without students' activities is not ideal. In order that the learning processes do not run in passive ways, teachers must always make efforts to activate students. Sixth, good teachers pay full attention to students more than just mere words. The problem that is often experienced at schools (by the students) is verbalism, in which the children recognize words but do not understand the meanings, and the students can memorize the lessons, but they are unable to understand the contents.

Seventh, good teachers link lessons to students' needs. Eight, good teachers have a specific goal as regards each lesson they deliver. Through the processes of education and teaching, there are certain goals to be achieved. Therefore, the purpose of teaching must be clear. Ninth, good teachers are not bound by one textbook merely. It is important to remember that the purpose of teaching is not to try to have the students master a textbook. Textbooks bind the teachers' personalities and curb their freedom to look for better materials and methods. Textbooks will also block self-thought and give a tendency to memorize. Good teachers will understand some weaknesses of textbooks and 
try to break away from the shackles of textbooks by searching for other materials. Tenth, good teachers not only teach in the sense of only conveying knowledge to students, but also always develop students' personalities. Teaching is a human duty. Teachers must not simply transfer the knowledge they have or know to the students, but they must pay attention to social, emotional, aesthetic, and ethical aspects. In addition, physical factors must also be considered. ${ }^{26}$

To be a teacher who can influence children in the direction of a good behavior towards God and His creatures is not an easy thing. There are conditions that must be met by an educator. Daradjat suggests that to become a teacher that can influence students towards the happiness of the world and the hereafter is actually not easy. ${ }^{27}$ The conditions that must be met include the following: First, faith in Allah SWT is a condition of being a good teacher. Teachers, in accordance with the objectives of Islamic Education, are impossible to educate children to fear of Allah if they themselves are not fearful of Him. Teachers are the examples for their students as Rasulullah SAW becomes an example for his people. The extent to which teachers are able to become good examples for their students is associated with how they are expected to succeed in educating students to become the next generation of good and noble people. Second, knowledge is a condition of being a teacher. Teachers must have a diploma, so they are allowed to teach. A diploma is not merely a piece of paper, but evidence that the owner has certain knowledge and abilities that the person needs for a position.

Subsequently, third, physical health is a condition of being a teacher. Physical health is often used as one of the conditions for those who apply to become teachers. Fifth, good behavior is a condition of being a teacher. The teachers' character is very important behind an effort to build up students' character. Teachers must be role models because children are imitating. Among the aims of education is to form good morals in children, and this point is only possible if teachers have good character. Good morals in Islamic education are the morals aligned with Islamic teachings, as exemplified by the main educator, Muhammad SAW. Among the teachers' morals are: loving their positions as teachers, being fair to all of their students, being patient and calm, being authoritative, happy, as well as humane, cooperating with other teachers, and cooperating with the community.

2011).

${ }^{26}$ Tohirin, Psikologi Pembelajaran Pendidikan Agama Islam (Jakarta: RajaGrafindo Persada, 27Zakiyah Daradjat, "Ilmu Pendidikan Islam” (Jakarta: Bumi Aksara, 2014). 
Ibnu Khaldun in Wajdi, Nizaruddin, dan Barid $^{28}$ recommended that teachers have a loving behavior and attitude towards their students, teach them with a gentle attitude and mutual understanding, do not apply harsh and violent behavior because such attitudes can endanger students, and they can even damage their mentality. The hard and rude behavior will subconsciously teach the students to the acts of lying, being lazy, talking dirty, and pretending to be obedient just because of the fear of punishment from teachers.

Based on the description of the above conditions, it can be concluded that to become a good teacher, an individual must have an Islamic personality, be fearful of Allah SWT, be responsible for the things that are charged to him/her, be knowledgeable, be physically healthy, be morally good, have social spirit, be honest, be sincere in giving knowledge as well as smart so that his/her behavior can provide talents for students, position himself/herself as a partner, be open to criticism from other people, and avoid being discriminatory.

\section{The Meanings of al-Rahmah in the Qur'an}

al-Rabmah is one of the terms most often repeated in the Qur'an and classified into lafadz musytarak (it has various meanings and interpretations). Among other things mentioned in QS Al-Baqarah verse 157: "Those are the ones upon who get blessings and mercy from their Lord. And, it is those who are the [rightly] guided (QS. 2:157)." Generally, however, if observed in detail, in the Qur'an in the Indonesian translation, the lafadz al-rahmah is seldom translated, and generally the lafadz becomes a general or standard term.

In the digital version of Al-Qur'an 3.1 which is affiliated with the Ministry of Religion's translation, the lafadz rahmat which represents al-rabmab is mentioned 75 times and the ones translated as "mercy" are only 5 verses (6: $12,64,17: 24,30: 21,57: 27,90: 17)$ and the rest is not translated, as stated in Surah Al-An'am verses 12 and 133:

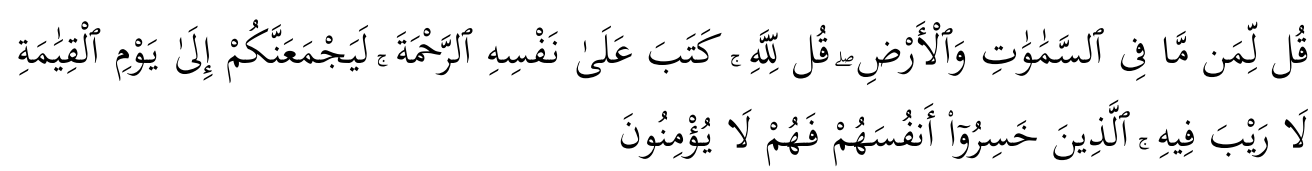

Say, "To whom belongs whatever is in the heavens and earth?" Say, "To Allah." He has decreed upon Himself mercy. He will surely assemble you for the Day of Resurrection, about which there is no doubt. Those who will lose themselves [that Day] do not believe (QS. 6:12)." Allah says:

${ }^{28}$ Wajdi, Nizaruddin, dan Barid, 2015) 


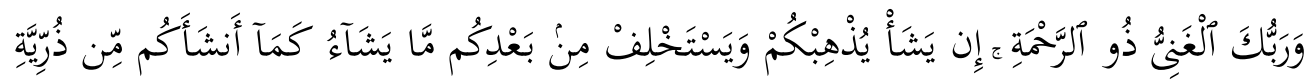

قَوْْرِ عَاخَرِينَ

And your Lord is the Free of need, the possessor of rabmat. If He wills, he can do away with you and give succession after you to whomever He wills, just as He produced you from the descendants of other people (QS. 6:133).

The differences in the understanding as shown above certainly have a "confusing" effect on understanding the meaning of a verse, in this case the understanding of the intentions of the lafadz rabmat in a verse, especially for the Muslims who understand the contents of the Qur'an only through the translation book. Therefore, with the rule of musytarak approach, the translation of verses containing the lafadz rabmat can be corrected for there is no strong reason why the lafadz rabmat is not translated or only in parentheses. Therefore, in the following sub-topics, the definitions of rahmah are elaborated both in terms of etymology and terminology.

\section{The Etymology of al-Rahmah in the Qur'an}

Rahmat which represnts al-rahmah comes from the root word rabimayarbamu-rabmat. In various forms, this word is repeated 338 times in the Qur'an,

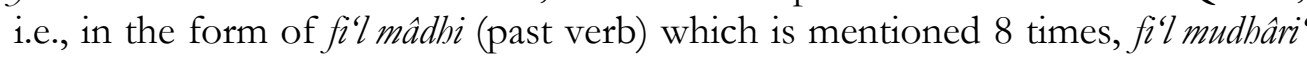
(future or continuous verb) 15 times, and fir amr (instructional verb) 5 times. The rest is mentioned in the form of ism (noun) with its various forms. The word rabmat itself is mentioned 145 times. $^{29}$

Faris in Mu'jam Maqayis mentioned that; "A word consisting of the letters ra, ha, and mim, basically refers to the meaning of "gentleness", "compassion", and "subtlety". From the root of this word was born the word rahima, which means "blood ties, brotherhood, or kinship relations," naming the uterus in a female reproductive organ because of the child who is born to receive an abundance of love and tenderness. ${ }^{30}$

Al-Asfahani, in the mufradhat gharibil al-Qur'an, mentions that rabmat is compassion that requires kindness for those who are blessed. This word is sometimes used with the meaning of ar-riqqat al-mujarradab (mere mercy) and is sometimes used with the meaning of al-Ihsân al-mujarrad dûn ar-riqqah (mere kindness without mercy). For example, if the word mercy rests on Allah, then the intended meaning is nothing but "mere kindness." Conversely, if it is based on humans, then the meaning in question is merely sympathy. Therefore,

\footnotetext{
${ }^{29}$ Baqy, Mu'jam Al-Mufharas Li Al-Fadzil Qur'anil Karim.

${ }^{30}$ Abu Husain Ahmad Ibnu Faris, Mu'jam Maqayiz, Al-Lughab (Al-Qahirah: Dar al-Fikr al-Aaraby, 1978).
} 
continued Al-Asfahani, it was narrated as the mercy that comes from Allah is in'âm (= gift or grace), and ifdhâl (excess) and what comes from man is riqqah (= mercy). ${ }^{31}$

In line with Al-Asfahani, Ibn Mansur ${ }^{32}$ in Lisân al-'Arab mentioned that the Arabs distinguish between the word rabmat which is based on Adam's posterity and that which is based on Allah. The word rahmah which is based on Adam's posterity is riqqat al-qalb wa 'athfib (= gentleness and compassion), while the word rahmat which is based on Allah is 'athfub wa Ihsânubu wa rizqubu (His mercy, kindness, and sustenance).

In the context of Indonesian-ness, the word rahmat according to Rahardjo comes from rahmah. Due to the effect of the pronunciation of Parsi into Indonesian, the word rahmah becomes rahmat (mercy). This word rahmah which is a verbal noun or a noun comes from the verb r-h-m. From this original word, there are other invented words in the Qur'an, e.g., rahima-arham, marhamah, rahim, rahman, and ruhm. The word rahima means having generosity, or to have mercy on someone, feeling sorry, wanting to entertain or please others (to be compassionate); arhàm, (plural forms of the reproductive organ, uterus, or rihm rahim; marhamah (or mercy), compassion; rahim, (or merciful), compassionate, all compassionate; rahman, (or merciful), all-merciful; rubm, (or tenderness). ${ }^{33}$

Therefore, when viewed in the etymological context, it is found that the various meanings contained in the word rahmah, all of these words indicate the nature and behavior that has an object and aims to provide happiness to the object such as compassion, empathy, generosity, and tenderness.

\section{The Terminology of al-Rah mah in the Qur'an}

In the context of terminology, the term rabmat whcih represents alrahmah used in the Qur'an almost all refers to Allah SWT as the main Subject as the Giver of rahmah. In other words, rahmat in the Qur'an speaks of various aspects related to the nature of compassion, kindness, and blessings that Allah gives to His creatures. This shows how much Allah loves His servants. There are at least 14 meanings for the terms related to the above which are spread throughout the Qur'anic verses. They are as follows: (1) Dinul Islam” QS. 2: 105;

${ }^{31}$ Al-Gharib al-Asfahani Abu al-Qasim al-Husain bin. tt Muhammad, Mufradat Fi Gharib Al-Qur'an (Beirut: Dar al-Ma'rifah, n.d.).

${ }^{32}$ Manzur

${ }^{33}$ Dawam Rahardjo, Ensiklopedi Al Qur'an: Tafsir Sosial Berdasarkan Konsep-Konsep Kunci (Jakarta: Paramadina, 2002). 
(2) Al-Iman". QS. 11:28; (3) Al-Jannat" (heaven), QS. 3:107; (4) Al-Mathar" (rain), QS. 7:57; (5) Al-ni'mah" (pleasure), QS. 4:83; (6) Al-Nubunab" (prophethood), QS. 38:9, 43:32; (7) Al-Qur'an", QS. 10:58; (8) Al-rizq" (blessings), QS. 17:100; (9) Al-Nashr, al-Fath" (assistance, victory), QS. 33:17; (10) Iiqab" (response), QS. 39:38; (11) Al-Mawaddah" (affection), QS. 48:29; (12) Al-Sa'ab" (freedom), QS. 2:178; (13) Al-Maghfirah" (forgiveness), QS. 6:12; and (14) Al-ishmab" (maintenance), QS. 11:43. ${ }^{34}$

In addition, from the root of the word rahima, several words were born which become the names and main characteristics of Allah SWT. For example, the word ar-râhim (الرَّاحِم) which is mentioned 6 times, ar-rahmân (الرَّحمَّانَ) which in a prayer indicates that He poured out a very perfect grace but was

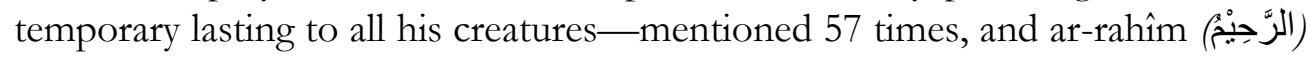
in which in a prayer shows that He continually and steadily devotes His mercy to those who obey Him in the Hereafter-referred to 95 times, once of which is mentioned for the personal attribution of the Prophet Muhammad SAW.

Therefore, it is clear that the main subject of al-rabmah revealed by the Qur'an is Allah SWT. He attributes Himself to the great love and affection (rah män), obliging to Himself the nature of rahmah (S. Al-An'âm [6]: 12). His Rahmah covers everything (S. Ghafir [40]: 7). His Rahmah was sown to all creatures, and none of the creatures did not receive rahmah even for a moment. In a hadith, it is stated that He is more loving to His servants than a mother to her child (HR. Bukhari). His Rahmah precedes His wrath (Narrated by Bukhari and Muslim). In fact, the calamity or trouble that befell on a servant in its essence is also the realization of His mercy. It is such a way that parents who punish their child who made mistakes become a proof of the parents' love for the child. In this way, His rahmah is a gift and divine blessing in all aspects of human lives.

Therefore, there are many verses of the Qur'an and the hadith of the Prophet which speak of the breadth of Allah's rahmah. Therefore, a servant must not despair of the acquisition of Allah's rahmah even if the servant has done something beyond the limit (S. Az-Zumar [39]: 53). A person who despairs of the acquisition of Allah's rahmah is labeled by the Qur'an as a heretic (S. Al-Hijr [15]: 56). Meanwhile, those who deny the verses of Allah and meet with Him are also labeled as those who despair of the acquisition of Allah's rahmah (S. Al-'Ankabūt [29]: 23).

Along with the breadth of His rahmah, the Qur'an reveals that Allah's rahmah is given to nature as a whole, including humans (S. Al-Anbiyā '[21]: 107),

${ }^{34} \mathrm{Abu}$ al-Faḍl Syihab ad-Dīn as-Sayyid Mahmud al-Baghdady Al-Alusy, Rūh Al-Ma'anny Fi Tafsìr Al-Qur'àn Al-Azìm Wa as-Sab'i Al-Mas̄àny (Beirut: Dār al-Kutub al-'Ilmiyah, 1978). 
believers (see for example, S Al-Nisā '[4]: 175, S. Al-A'râf [7]: 52; S. At-Tawbah [9]: 61; S. Hûd [11]: 57), people who hold firm in their faith (S. Anas' [4]: 175), people who do good deeds (S. Al-Jasiiyah [45]: 30), those who do good (S. Luqmān [31]: 3), people who surrender (S. An-Naḥl [19]: 89), as well as people (followers) who are convinced (S. Al-Jasiiyah (45): 20).

The Rahmah which is revealed by Allah to the universe in general takes the form of sending prophets and messengers (S. Al-Anbiyā '[21]: 107) and the book of guidance (S. Luqmân [31]: 3). The rahmah is given specifically to those who believe and obey Him in the form of avoidance from the class of people who are losers (S. Al-Baqarah [2]: 64), avoidance of doom (see for example S. Al-A ' rāf [7]: 72; S. Hūd [11]: 58, 63, 66, 73, and 94; and S. An-Nūr [24]: 14), protection from the temptations of Satan (S. An-Nisā '[ 4]: 83), avoidance of deception by a group of people (followers) who are heretical (S. An-Nisā '[4]: 113), as well as giving privileges and ladunni knowledge that is directly from His side (S. Al- Kahf [18]: 65).

The Islamic scholars concluded that Allah's rahmah to His creatures is divided into two, i.e., the general rahmah and the special rahmah. The general Rahmab is given to all His creatures without exception, while the special rahmah is only given to His creatures that believe and obey Him. Meanwhile, the Islamic scholars also argue that with His nature of rahmah, Allah SWT gives His gift of rahmah in general to all His creatures in this world without subtlety, while with the nature of His Rabim, Allah SWT gives His rahmah specifically to those who believe and obey Him in the hereafter (see: Shabih Muslim, Book of Repentance, chapter 1315 number 4944).

As for rahim (j) which is the nature of the Prophet, it is mentioned in QS. At-Tawbah [9]: 128:

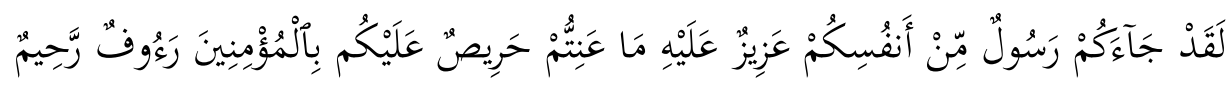

There has certainly come to you a Messenger from among yourselves. Grievous to him is what you suffer; [he is] concerned over you and to the believers is kind and merciful.

In the above verse, four main characteristics of the Prophet are

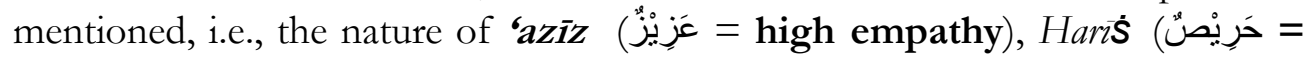

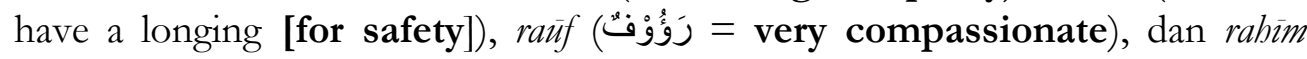
(jَجِ = very merciful). These four characteristics are mentioned in the affirmation context of Allah SWT to the Meccan Arabs that have been sent (come) to them an apostle from among themselves (Arab descendants of the Bani Hashim) who have a high degree of empathy for the difficulties and sufferings they experience, desperately want faith and salvation for them, and 
very compassionate and very merciful to the believers. The phrase raîfun rabimun which closes this verse is interpreted by some exegesis experts as: "very compassion for those who obey, and very gentle toward those who sin".

\section{Religious Educators}

The Quran uses three terms in giving an understanding of educator, muallim, muaddib, and murabby. Education experts, however, use the term murabby more often to define the word educator in Islamic education. ${ }^{35}$ The argument is reasonable because the word is based on the word Rabb, which comes from the word rabba-yurabby, which etymologically means to maintain. This means that the task of an educator explicitly not only provides learning materials to students and then receives an award from the services provided by the teacher, but also extends to more than that. The teacher is required to maintain and develop students' potential, so students are creative and have good morals either to Allah or to humans.

In order for teachers to carry out their duties — not only in teaching - in developing students' creativity, Torrance et al. as cited in Langgulung argue that at least three principles or methods can be used by teachers to promote students to become more creative, namely recognizing students' potential, respecting students' opinions and ideas, and providing stimulus to students with problems that are contradictory and provocative in order to generate curiosity and imaginational thought. ${ }^{36}$

The proposition above provides a justification that an educator must have a caring and sensitive attitude towards students' potential, so the conditions when the teachers have faced students both in the classroom while providing learning materials and outside the classroom really position themselves as partners for the students by giving appreciation to good and capable achiever students through gift giving, compliments with words like "good" or "extraordinary". Then, the teachers must also provide guidance that is full of patience for the students who are slow to receive information compared to the fellow students, in order to create harmonization and familiarity between educators and students. Langgulung further argued that changes in individuals' lives may be caused by simple words and behavior but are memorable from the teachers to the students, such as recognizing students' intelligence and or a simple pat on the shoulder as a sign of familiarity. ${ }^{37}$

\footnotetext{
${ }^{35}$ Ahmad Sulaiman, "Karakteristik Guru Perspektif M. Quraish Shihab Dalam Tafsir Al-Misbah," Edu-Riligia: Jurnal Ilmu Pendidikan Islam Dan Keagamaan 1, no. 1 (2017).

${ }^{36}$ Hasan Langgulung, Manusia Dan Pendidikan: Suatu Analisis Psikologis, Filsafat Dan Pendidikan (Jakarta: Pustaka Alhusna Baru, 2004).

${ }^{37}$ Langgulung.
} 
It cannot be denied that good teachers had given birth to new humans in the past, and with their works they had been able to contribute to the scientific development of the world both in the West and the Islamic world, such as Edison, Einstein, Ibn Sina, Al Ghazali, Ibn Rusyd and many others, all through similar experiences. On the contrary, if in learning processes, teachers never give appreciation, do not respect students' abilities, even suspect, intimidate, and position students as competitors, then of course the long learning processes will not give birth to creative and independent human beings or future contributions.

In other words, creating students to be creative individuals, of course, also starts from creative teachers. The current phenomenon (politics which have implications for the national education system), precisely-in the author's opinion-has bound the teacher's creativity individually. The statements and policies issued by the officials who are authorized to regulate the systems of human resources and education seem to be the antithesis of past education policies, which curb teachers and lecturers with such tight supervision. Teachers are becoming more like dead screws that are only moved according to the wishes of the educational bureaucracy from the center. They only dare to work based on the operational guidelines and technical guidelines. ${ }^{38}$ It is especially when the central government has given appreciation through teachers' and lecturers' certification programs that increasingly confine teachers and lecturers to meet the target of learning volume.

The reality in the field is that now the teachers who have high creativity and have the initiative to improve their competences in both personal, pedagogical, professional and social competencies as well as individual innovation almost do not exist anymore. This is a small part of the impact seen in the field, especially in the case of teachers who seem to race and "hunt" for the achievement of lesson hours set by the government, so not a few teachers must complete the requirement by asking for teaching hours at other schools. This reality provides a big question: will the quality of learning provided by teachers be guaranteed? Will it create fun and memorable learning for the students?

For this reason, Islam provides guidance through the Qur'an and hadith on how the figure of a religious educator (especially in the meaning of the verses of rahmab), which is expected not only to receive wages from services through the learning process given by the teacher to students, but more than that, sincerity, empathy, caring, and loving teacher to students both inside and

${ }^{38}$ Darmaningtyas, Pendidikan Rusak-Rusakan (Yogyakarta: LKiS, 2011). 
outside the classroom. Thus, the creative, innovative, and professional teachers who position their students as learning partners exist. Eventually, the practices of these religious teachers may create fun and meaningful learning, so a good process will lead the students to be creative, intelligent, innovative, and have good personalities, and also be able to become better human beings in the future.

If it is seen in the previous discussion-on the verses about the concept of rahmah - when quoting one of the verses of the Qur'an relating to the word rabim as in Surah Al Isra, there is a verse that gives an illustration of the meaning of the womb. This concerns the parents' relationship with the child stating in verses 23 and 24 in Surab al-Isra.

It is clearly illustrated from the verses that the relationship between parents and children is united in a special love, the rabim (womb). Therefore, in educating those between educators and students, teachers and students' relationship is similar to the relationship between parents and their children. With that, a harmonious relationship will occur; intense communication will occur due to love and compassion to make a massive communication, so it will give birth to people who are in accordance with the wishes of their parents, as exemplified by Lukman with very close affection.

Referring to the meanings of al-rahmab in these verses, when formulated into educators' personalities, there can be grouped into three terms of the typology of religious educators, namely the characteristics of Rabbaniyah, nabawiyah, and insaniyah. An educator with the intended rabbany character is the one with all the behavior and character of the educator who relies on the attributes of godliness, such as prioritizing the cultivation of strong faith in students, so they understand how to walk based on the essential truths (Islam) as stated in QS. 2: 105 and 11: 28, giving appreciation to students who excel and have good character (QS: 3: 107, 4: 83, 7:57 and 17: 100), and giving extensive knowledge to students (10: 58). In addition, these educators are also being sincere in carrying out tasks, forgiving (Surah 2: 178, 6:12), and caring for students well (Qur'an 11: 43). When these traits were possessed by educators, this means that the educators have positioned themselves as Murabby for their students.

Educators who have nabawiyah character-or a prophetic personalityis a typology of personality reflected in the behavior and character of the Prophet, i.e., religious, loving, assertive, and strong but not selfish (Qur'an, 48:29), highly emphatic, and have a strong will, so students develop and are useful, strong, and compassionate (Qur'an 9: 128), inclusive and tolerant (Qur'an 21: 107). This shows that Islam in fact does not provide both the 
ideological framework and the network platform upon which violent elements develop like the conclusion drawn by Amaechi. ${ }^{39}$

Furthermore, the educators with the insaniyah characteristic are reflected in the behavior and character of the educators who position themselves as parents for their students. Parental affection is reflected in the educators' love, and the teachers have even been able to avoid positioning students as mere objects in learning processes but as the subjects of the learning per se. Educators have assumed that students are the learning partners and discussion partners. Educators with the al-rahmah personality are well aware that without students educators will lose their own identities. The educators and students give each other, complement and respect each other, in order to create a humanistic, harmonious and meaningful learning atmosphere.

When an educator has all the personality types mentioned above, then the educator can be categorized as an educator with al-rahmah personalities as described in the following figure:

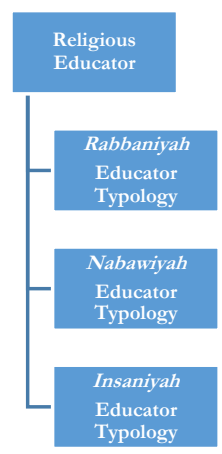

Figure 1. Religious Educators' al-Rahmah Personalities

To achieve the typology of religious educators in the perspective of alrahmah related verses with all the indicators described above, the psychological elements that influence them are at least summarized in the following: 1) Having strong spirituality and religiosity; 2) Having competencies (personal, pedagogical, professional, and social competences); 3) Smart; 4) always being long-term oriented; and 5) Communicative.

${ }^{39}$ Amaechi, "Islam as a Resource for Violance in the Nogerian Boko Haram." 


\section{Conclusion}

In the theme of the word al-rahmah, it has a variety of meanings and all of the meanings indicate the nature and behavior that have an object and aim to provide happiness to the object such as affection, empathy, generosity, and tenderness. Educators with such personalities are religious educators with three characters, i.e., Rabbaniyah, Nabawiyah, and Insaniyah that are bound by a strong belief in the power of Allah SWT, observe the Islamic Law well, and are fully aware that Allah SWT always oversees their activities. The requirements that must be possessed by every religious educator include: having high spirituality and religiosity (fearing of Allah and having a noble character), having good competences, extensive knowledge as well as being intelligent, future-oriented, communicative (conveying knowledge with patience, sincerity, and with a method that is good and easy to understand by students), open to critic, authoritative, fair, non-discriminatory, pleasant, and having polite speech.

\section{Bibliography}

Abery, Brian H., and Marianna Harutyunyan. "Enhancing the Social and Psychological Inclusion of Students with Special Education Needs.” In Inclusive Education Strategies: A Textbook, edited by Paula Frederica Hunt Renáta Tichá, Brian H. Abery, Christopher Johnstone, Alvard Poghosyan, 166. Armenia: UNICEFF country offi, 2018.

Al-Alusy, Abu al-Faḍl Syihab ad-Dīn as-Sayyid Mahmud al-Baghdady. Rūh AlMa'āny Fi Tafsìr Al-Qur'ān Al-Azìm Wa as-Sab'i Al-Masiāny. Beirut: Dār al-Kutub al-'Ilmiyah, 1978.

Amaechi, Kingsley Ekene. "Islam as a Resource for Violance in the Nogerian Boko Haram." Nordic Journal of Religion and Society 29, no. 2 (2016).

Anam, Saeful. "Tinjauan Filosofis Tentang Pendidikan: Analisa Terhadap Pendidik Dalam Pendidikan Islam.” MIY AH: Jurnal Studi Islam 12, no. 1 (2017): 1-18.

Arora, Ridhi, and Santosh Rangnekar. "Moderating Mentoring Relationships and Career Resilience: Role of Conscientiousness Personality Disposition." Journal of Workplace Behavioral Health 31, no. 1 (2016): 1936. https://doi.org/10.1080/15555240.2015.1074052.

Baqy, Muhammad Fuad Abdul. Mu'jam Al-Mufharas Li Al-Fadzil Qur'anil Karim. Al-Qahirah: Darul Hadis, 1996.

Barrick, Murray R., Michael K. Mount, and Judy P. Strauss. "Conscientiousness and Performance of Sales Representatives: Test of the Mediating Effects of Goal Setting." Journal of Applied Psychology 78, no. 5 (1993): $715-22$.

Bozionelos, Nikos, Giorgos Bozionelos, Panagiotis Polychroniou, and Kostantinos Kostopoulos. "Mentoring Receipt and Personality: 
Evidence for Non-Linear Relationships." Journal of Business Research 67, no. 2 (2014): 171-81. https://doi.org/10.1016/j.jbusres.2012.10.007.

Carvalho, L. F., A. R.L. Costa, F. Otoni, and P. Junqueira. "ObsessiveCompulsive Personality Disorder Screening Cut-off for the Conscientiousness Dimension of the Dimensional Clinical Personality Inventory 2." European Journal of Psychiatry 33, no. 3 (2019): 112-19. https://doi.org/10.1016/j.ejpsy.2019.05.002.

Daradjat, Zakiyah. "Ilmu Pendidikan Islam.” Jakarta: Bumi Aksara, 2014.

Darmaningtyas. Pendidikan Rusak-Rusakan. Yogyakarta: LKiS, 2011.

Domović, Vlatka, Vizek Vidović Vlasta, and Dejana Bouillet. "Student Teachers' Beliefs about the Teacher's Role in Inclusive Education." European Journal of Special Needs Education 32, no. 2 (2017): 175-90. https://doi.org/10.1080/08856257.2016.1194571.

Faris, Abu Husain Ahmad Ibnu. Mu'jam Maqayiz, Al-Lughah. Al-Qahirah: Dar alFikr al-'Araby, 1978.

Feryok, Anne. "Teaching for Learner Autonomy: The Teacher's Role and Sociocultural Theory." Innovation in Language Learning and Teaching 7, no. 3 (2013): 213-25. https://doi.org/10.1080/17501229.2013.836203.

Gardner, Howard. Multiple Intelligences: Kecerdasan Mayemuk: Teori Dan Praktis, Diterjemabkan Oleh Alexander Sindoro. Jakarta: Interaksara, 2013.

Göncz, Lajos. "Teacher Personality: A Review of Psychological Research and Guidelines for a More Comprehensive Theory in Educational Psychology." Open Review of Educational Research 4, no. 1 (2017): 75-95. https://doi.org/10.1080/23265507.2017.1339572.

Hajhosseini, Mansoureh, Saeid Zandi, Sediqeh Hosseini Shabanan, and Yaser Madani. "Critical Thinking and Social Interaction in Active Learning: A Conceptual Analysis of Class Discussion from Iranian Students' Perspective." Curriculum \& Teaching Studies, 2016, 1-9. https://doi.org/10.1080/2331186X.2016.1175051.

Huver, Rose M.E., Roy Otten, Hein de Vries, and Rutger C.M.E. Engels. "Personality and Parenting Style in Parents of Adolescents." Journal of Adolescence 33, no. 3 (2010): 395-402. https://doi.org/10.1016/j.adolescence.2009.07.012.

Indrawati, Farah. "Pengaruh Kemampuan Numerik Dan Cara Belajar Terhadap Prestasi Belajar Matematika." Formatif: Jurnal Ilmiah Pendidikan MIPA 3, no. 3 (2015).

Jalaluddin. Psikologi Agama. Jakarta: Raja Grafindo Persada, 2016.

Kalantzis, Mary, and Bill Cope. "Learner Differences in Theory and Practice." Open Review of Educational Research 3, no. 1 (2016): 85-132. https://doi.org/10.1080/23265507.2016.1164616. 
Kitamura, Toshinori, Noriko Shikai, Masayo Uji, Hidetoshi Hiramura, Nao Tanaka, and Masahiro Shono. "Intergenerational Transmission of Parenting Style and Personality: Direct Influence or Mediation?” Journal of Child and Family Studies 18, no. 5 (2009): 541-56. https://doi.org/10.1007/s10826-009-9256-z.

Kuusisto, Arniika, and Liam Gearon. "The Life Trajectory of the Finnish Religious Educator.” Religion \& Education 44, no. 1 (2017): 39-53.

Langgulung, Hasan. Manusia Dan Pendidikan: Suatu Analisis Psikologis, Filsafat Dan Pendidikan. Jakarta: Pustaka Alhusna Baru, 2004.

Lantolf, James P, and Steven L Thorne. "Sociocultural Theory and Second Language Learning." Theories in Second Language Acquisition, 2006, 197221. https://doi.org/10.1177/0022219409345018.

Lee, Queenie A.Y., and Mantak Yuen. "The Role of Teacher Care in Determining Academic Success of Community College Students: A Case Study from Hong Kong." Pastoral Care in Education 37, no. 2 (2019): 94-107. https://doi.org/10.1080/02643944.2019.1618376.

Li, Jing, Xiaohong Yang, and Cheryl J. Craig. "A Narrative Inquiry into the Fostering of a Teacher-Principal's Best-Loved Self in an Online Teacher Community in China." Journal of Education for Teaching 45, no. 3 (2019): 290-305. https://doi.org/10.1080/09589236.2019.1599508.

Lucas, Richard E., and M. Brent Donnellan. "Enhancing Transparency and Openness at the Journal of Research in Personality." Journal of Research in Personality 68 (2017): 1-4. https://doi.org/10.1016/j.jrp.2017.03.002.

Maaranen, Katriina, Harri Pitkäniemi, Katariina Stenberg, and Liisa Karlsson. "An Idealistic View of Teaching: Teacher Students' Personal Practical Theories." Journal of Education for Teaching 42, no. 1 (2016): 80-92. https://doi.org/10.1080/02607476.2015.1135278.

Mangkunegara, AA Anwar Prabu, and Mela Puspitasari. "Kecerdasan Emosi Guru, Stres Kerja, Dan Kinerja Guru SMA.” Jurnal Kependidikan: Penelitian Inovasi Pembelajaran 45, no. 2 (2015).

Manzur, Ibnu. Lisan Al-Arab. Jilid 14. Bairut: Daru Sadir, n.d.

Matsumoto, Yoshihiko, Akihito Suzuki, Toshinori Shirata, Nana Takahashi, Keisuke Noto, Kaoru Goto, and Koichi Otani. "Implication of the DGKH Genotype in Openness to Experience, a Premorbid Personality Trait of Bipolar Disorder." Journal of Affective Disorders 238, no. May (2018): 539-41. https://doi.org/10.1016/j.jad.2018.06.031.

Muhammad, Al-Gharib al-Asfahani Abu al-Qasim al-Husain bin. tt. Mufradat Fi Gharib Al-Qur'an. Beirut: Dar al-Ma'rifah, n.d.

Pörn, Michaela, and Katri Hansell. "The Teacher's Role in Supporting TwoWay Language Learning in Classroom Tandem." International Journal of Bilingual Education and Bilingualism, 2017, 1-16. https://doi.org/10.1080/13670050.2017.1379946. 
Rachma, Diah Ayu, and Seger Handoyo. Hubungan Antara Kepribadian Dengan Kemampuan Adaptasi Lintas Budaya Pada Expatriate Leader. Surabaya: Universitas Airlangga, 2016.

Rahardjo, Dawam. Ensiklopedi Al Qur'an: Tafsir Sosial Berdasarkan Konsep-Konsep Kunci. Jakarta: Paramadina, 2002.

Roberts, Brent W., and Daniel Mroczek. "Personality Trait Change in Adulthood." Current Directions in Psychological Science 17, no. 1 (2008): 3135.

Rosenfeld, Melodie, and Sherman Rosenfeld. "Developing Effective Teacher Beliefs about Learners: The Role of Sensitizing Teachers to Individual Learning Differences." Educational Psychology: An International Journal of Experimental Educational Psychology 28, no. 3 (2008): 245-72. https://doi.org/10.1080/01443410701528436.

Schuler, H., and M. Prochaska. "Development and Construct Validation of a Job-Related Achievement Motivation Test. Diagnostica , 46 , 61 - 72." Diagnostica 46 (2000): 61-72.

Septianingrum, Anisa. "Studi Kompetensi Sosial Dan Kepribadian Mahasiswa Program PPL (Praktik Pengalaman Lapangan) Prodi Pendidikan Sejarah Angkatan 2010 Di Kota Magelang." Risalah 3, no. 10 (2016).

Shen, Jianhong, and Thomas J Palmeri. "Modelling Individual Difference in Visual Categorization." Visual Cognition 24, no. 3 (2016): 260-83. https://doi.org/10.1080/13506285.2016.1236053.

Speed, Brittany C., Brady D. Nelson, Greg Perlman, Daniel N. Klein, Roman Kotov, and Greg Hajcak. "Personality and Emotional Processing: A Relationship between Extraversion and the Late Positive Potential in Adolescence." Psychophysiology 52, no. 8 (2015): 1039-47. https://doi.org/10.1111/psyp.12436.

Speed, Brittany C, Brady Nelson, Jennifer N Bress, Greg Hajcak, Stony Brook, and Stony Brook. "RUNNING TITLE: Parenting Style and Observational ERPs TITLE: Authoritarian Parenting Predicts Reduced Electrocortical Response to Observed Adolescent Offspring Rewards Amanda R. Levinson, B.S.," 2016.

Sulaiman, Ahmad. "Karakteristik Guru Perspektif M. Quraish Shihab Dalam Tafsir Al-Misbah." Edu-Riligia: Jurnal Ilmu Pendidikan Islam Dan Keagamaan 1, no. 1 (2017).

Suslow, Thomas, Christian Lindner, Harald Kugel, Boris Egloff, and Stefan C. Schmukle. "Using Implicit Association Tests for the Assessment of Implicit Personality Self-Concepts of Extraversion and Neuroticism in Schizophrenia." Psychiatry Research 218, no. 3 (2014): 272-76. https://doi.org/10.1016/j.psychres.2014.04.023. 
Tichá, Renáta, Brian H. Abery, Kristen McMaster, Armenuhi Avagyan, Siranush Karapetyan, and Zhanna Paylozyan. "Instructional Strategies for Inclusive Classrooms: PALS, Cooperative Learning, Direct Instruction and Play-Based Strategies." In Inclusive Education Strategies: A Textbook, edited by Paula Frederica Hunt Renáta Tichá, Brian H. Abery, Christopher Johnstone, Alvard Poghosyan, 105-23. Armenia: UNICEFF country offi, 2018.

Tohirin. Psikologi Pembelajaran Pendidikan Agama Islam. Jakarta: RajaGrafindo Persada, 2011.

Tomlinson, C. A. "Grading and Differentiation Paradox or Good Practice? Theory into Practice" 44, no. 3 (2005): 262-69.

Turuk, Mamour Choul. "The Relevance and Implications of Vygotsky's Sociocultural Theory in the Second Language Classroom." ARECLS 5 (2008): 244-62.

Valchev, Velichko H., Fons J.R. van de Vijver, Deon Meiring, J. Alewyn Nel, Carin Hill, Sumaya Laher, and Byron G. Adams. "Beyond Agreeableness: Social-Relational Personality Concepts from an Indigenous and Cross-Cultural Perspective." Journal of Research in Personality 48, no. 1 (2014): $17-32$. https://doi.org/10.1016/j.jrp.2013.10.003.

Vygotsky, Lev. "Interaction between Learning and Development." Readings on the Development of Children. New York, 1978. https://doi.org/10.1016/S0006-3495(96)79572-3.

Wajdi, Nizaruddin, and Muh Barid. "Pendidikan Ideal Menurut Ibnu Khaldun Dalam Muqaddimah." Jurnal Lentera: Kajian Keagamaan, Keilmuan Dan Teknologi 1, no. 2 (2015): 272-83. https://doi.org/10.1111/j.15404781.1969.tb04998.x.

Warsah, Idi. "Pendidikan Keimanan Sebagai Basis Kecerdasan Sosial Peserta Didik: Telaah Psikologi Islami." Psikis: Jurnal Psikologi Islami 4, no. 1 (2018): 1-16.

White, E. Jayne, and Mikhail Gradovski. "Untangling (Some) Philosophical Knots Concerning Love and Care in Early Childhood Education." International Journal of Early Years Education 26, no. 2 (2018): 201-11. https://doi.org/10.1080/09669760.2018.1458602. 